\title{
Article \\ The Effect of Fertilization with Spent Mushroom Substrate and Traditional Methods of Fertilization of Common Thyme (Thymus vulgaris L.) on Yield Quality and Antioxidant Properties of Herbal Material
}

\author{
Cezary A. Kwiatkowski (D) and Elżbieta Harasim *(D) \\ Department of Herbology and Plant Cultivation Techniques, University of Life Sciences, Akademicka 13, \\ 20-950 Lublin, Poland; czarkw@poczta.onet.pl \\ * Correspondence: elzbieta.harasim@up.lublin.pl; Tel.: +48-814456820
}

\section{check for}

updates

Citation: Kwiatkowski, C.A.;

Harasim, E. The Effect of Fertilization with Spent Mushroom Substrate and Traditional Methods of Fertilization of Common Thyme (Thymus vulgaris L.) on Yield Quality and Antioxidant Properties of Herbal Material. Agronomy 2021, 11, 329. https:// doi.org/10.3390/agronomy11020329

Academic Editors: Anna Kocira and Katarzyna Panasiewicz

Received: 21 January 2021

Accepted: 9 February 2021

Published: 12 February 2021

Publisher's Note: MDPI stays neutral with regard to jurisdictional claims in published maps and institutional affiliations.

Copyright: (c) 2021 by the authors. Licensee MDPI, Basel, Switzerland. This article is an open access article distributed under the terms and conditions of the Creative Commons Attribution (CC BY) license (https:/ / creativecommons.org/licenses/by/ $4.0 /)$.

\begin{abstract}
This experiment was designed to determine the effect of spent mushroom substrate, farmyard manure, and mineral fertilization with nitrogen, phosphorus, and potassium on the yield and quality of raw material obtained from two cultivars ("Słoneczko" and "De Dolj") of common thyme. Unfertilized plots with thyme crops were included as the control treatment. Different row spacings $(30 \mathrm{~cm}$ and $40 \mathrm{~cm}$ ) represented the second experimental factor. The highest total yield of thyme raw material was found in the treatment with mineral NPK fertilization, but also in the treatments where spent mushroom substrate (SMS) and mineral NPK fertilization were applied at a ratio of 50:50\%. Fertilization with SMS alone (100\%) yielded smaller production effects, but they were higher than in the case of fertilization with manure. The high suitability of spent mushroom substrate applied alone or supplemented with mineral fertilization at different rates in spring was confirmed by the best quality parameters and antioxidant properties of the raw material. The use of a wider row spacing $(40 \mathrm{~cm})$ resulted in a higher yield of thyme raw material than in the case of a narrower one $(30 \mathrm{~cm})$. The narrower row spacing significantly positively affected some of the analyzed quality parameters of the harvested raw material, such as: essential oil content, polyphenol content, and antioxidant activity. The thyme cultivar "Słoneczko" proved to be absolutely more beneficial in terms of yield quantity and quality than the foreign cultivar "De Dolj".
\end{abstract}

Keywords: common thyme; cultivars; SMS; manure; NPK fertilization; row spacing; yield; quality; antioxidant activity

\section{Introduction}

Common thyme (Thymus vulgaris L.) is a plant that has a high capacity to adapt to environmental conditions. Due to this, it is grown across Europe in moderate climate areas [1]. Improvement of the agronomic practices used in the growing of this popular species still continues, in particular, in the context of implementing organic and environmentally friendly methods (e.g., seeking fertilization alternatives instead of the standard mineral NPK fertilization method) that are capable of positively affecting the yield and quality of herbal material [2,3]. Owing to the dynamic development of mushroom production in many European countries, in recent years spent mushroom substrate has contributed a substantial part to organic waste materials. The use of this waste for fertilization purposes can be a prospective form of its management. During mushroom cultivation, for every $1 \mathrm{~kg}$ of grown mushroom fruiting bodies, $5 \mathrm{~kg}$ of spent mushroom substrate (SMS) is produced [4]. The average mushroom farm throws away 25 tons of SMS per month [5]. Spent mushroom substrate is formally approved for use as fertilizer in agriculture and horticulture [6-8]. 
Spent mushroom substrate (SMS) is characterized by a high content of organic matter, good availability of macro- and micro-nutrients (in both total and available form), neutral $\mathrm{pH}$, a favorable narrow $\mathrm{C} / \mathrm{N}$ ratio, and a low content of heavy metals [8-11].

Most commonly, the research on SMS has focused on the enzymatic activity of the residual mycelium and its ability to produce lignocellulosic enzymes such a laccase, $x y-$ lanase, lignin peroxidase, cellulose and hemicellulose as a cheap source of bioremediation, animal feed and energy feedstock [12,13]. The advantages of using SMS as a soil fertilizer over chemical fertilizer include the fact that it delivers a slow-release of nutrients that will not burn crops upon application. Additionally, SMS has a low bulk density that indicates its relatively porous medium that can enhance the structure of the soils it is amended to [14]. However, excessive application of SMS to the soil can lead to nutrient loss through leaching, which may cause water or soil pollution. One method of pre-treatment of SMS prior to its use, is passive leaching by rainfall and snowmelt [15]. Medina et al. [16] suggest that the appropriate timing for spent mushroom substrate additions to the soil should be approximately one month prior to planting. Their investigation also showed that the addition of SMS increased the soil respiration rate and phosphatase activity.

The use of spent mushroom compost in agriculture for the fertilization of arable land and permanent grassland has been proposed in fruit and vegetable growing, as well as for the establishment and maintenance of green spaces [17]. Some authors [18,19] have reported that spent mushroom compost has a positive effect on the productivity of grasses, cereals, some vegetable plants, and flowers. Nonetheless, experiments on the possibility of using this fertilizer in herbal plantations represent a research "niche". Some researchers $[8,20,21]$ are of the opinion that in planning fertilization with spent mushroom substrate, one should take into account that in the first year after SMS application, plants are able to utilize only $20-25 \%$ of the nitrogen contained in the substrate, in addition to only $20-40 \%$ of the phosphorus, and $65-85 \%$ of the potassium. Therefore, it seems justified to supplement SMS fertilization with mineral NPK fertilization. Moreover, spent mushroom substrate is characterized by great variation and an unbalanced chemical composition, which is undoubtedly a drawback that makes it necessary to continually control the chemical composition of this fertilizer and replenish missing elements in order to improve its fertilizing qualities [22-24].

In turn, appropriate row spacing (seeding density) is a non-input agronomic factor that affects the yield quantity and quality of herbal plants. On the one hand, the results of some studies demonstrate, for instance, that wider row spacings can contribute to increased crop productivity, while on the other hand, this can worsen the quality of plant material obtained $[25,26]$. The applied seeding density also has an impact on the effective utilization of fertilization by crop plants [27].

Taking into account the above considerations, it was hypothesized that fertilization with spent mushroom compost (applied alone or supplemented with mineral NPK fertilization) would contribute to obtaining satisfactory yields of thyme raw material of high health-promoting quality, which would allow us to consider this fertilizer to also be suitable for use in herbal cultures. It was also assumed that the thyme cultivars that were compared, could exhibit different responses to fertilization methods and levels. Furthermore, the assumption was made that different row spacings used in the plantation could affect the productivity and quality of the thyme raw material. Significant interactions between the experimental factors were assumed (especially in the context of fertilization methods of thyme cultivars-i.e., Polish and Romanian).

The aim of this study was to determine the effect of SMS (applied in pure form or supplemented with different rates of NPK), as an alternative organic fertilization method, on the yield and various quality parameters of raw material obtained from two thyme cultivars. This was then compared with standard mineral NPK fertilization and manure fertilization, in relation to different row spacings of this herbal plant. Determining the antioxidant parameters of the herbal material was considered to be of particular importance. The confirmation of the possibility of fertilization (especially SMS fertilization) to 
influence the content of natural antioxidants in the raw material of thyme would be of great practical importance.

\section{Materials and Methods}

\subsection{Experimental Design}

The experiment on growing common thyme was conducted over the period 2017-2019 in Fajsławice (the central Lublin region, Poland). It was set up as split-split-block design with 3 replicates. The total experimental area was $504 \mathrm{~m}^{2}$. Treatments with the two thyme cultivars were the experimental blocks. These blocks comprised alternately arranged plots with 2 different row spacings of thyme. A total of 7 fertilization treatments were randomly assigned to these 2 thyme cultivars in addition to the 2 different row spacings of this herbal plant. The experiment included a total of 84 plots with a single plot area of $6 \mathrm{~m}^{2}$ (each plot was rectangular with the dimensions $2.0 \mathrm{~m} \times 3.0 \mathrm{~m}$ ). The characteristics analyzed in this study were determined in each of the 84 experimental plots. The specific design of this field experiment is shown in Figure 1.

\begin{tabular}{|c|c|c|c|c|c|c|c|c|c|c|c|}
\hline D & $\mathrm{G}$ & B & 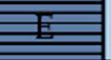 & C & 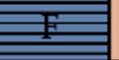 & F & B & E & G & A & D \\
\hline C & E & D & 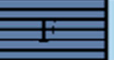 & B & 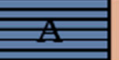 & C & G & D & E & $\mathrm{F}$ & A \\
\hline G & 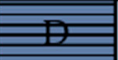 & A & 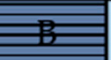 & $\mathrm{D}$ & 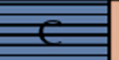 & $E$ & $C$ & $\mathrm{~F}$ & $\mathrm{D}$ & B & $\mathrm{E}$ \\
\hline E & $\mathrm{B}$ & E & 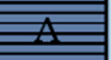 & $\mathrm{F}$ & 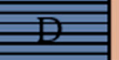 & B & A & B & $\mathrm{F}$ & C & G \\
\hline A & 害要 & C & $\bar{G}$ & $E$ & $\bar{B}$ & D & E & C & A & G & B \\
\hline $\mathrm{F}$ & 帮 & G & 王王 & A & 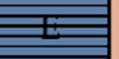 & G & D & A & C & $\mathrm{E}$ & $\mathrm{F}$ \\
\hline B & 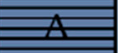 & $\mathrm{F}$ & e & G & 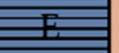 & A & $\mathrm{F}$ & G & B & D & C \\
\hline
\end{tabular}

Explanations:
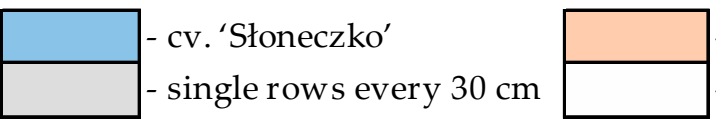
- cv. 'De Dolj'
- single rows every $40 \mathrm{~cm}$

A, B, C, D, E, F, G - fertilization

Figure 1. Design of the field experiment on the cultivation of thyme.

The experiment included the following factors:

I. Two cultivars of common thyme:

1. cv. "Słoneczko" (Polish cultivar)

2. cv. "De Dolj" (Romanian cultivar)

II. Type of fertilization:

A. control treatment-without fertilization

B. mineral NPK fertilization $(100 \%)$ : N-50, $\mathrm{P}-40, \mathrm{~K}-60 \mathrm{~kg} \mathrm{ha}^{-1}$

C. spent mushroom substrate (SMS) $(100 \%): 15 \mathrm{tha}^{-1}$

D. $\quad$ SMS $(70 \%)+$ NPK $(30 \%): 10.5 \mathrm{t} \mathrm{ha}^{-1}+\mathrm{N}-15, \mathrm{P}-12, \mathrm{~K}-18 \mathrm{~kg} \mathrm{ha}^{-1}$

E. $\quad$ SMS $(50 \%)+\mathrm{NPK}(50 \%): 7.5 \mathrm{t} \mathrm{ha}^{-1}+\mathrm{N}-25, \mathrm{P}-20, \mathrm{~K}-30 \mathrm{~kg} \mathrm{ha}^{-1}$

F. $\quad$ SMS $(30 \%)+\mathrm{NPK}(70 \%): 4.5 \mathrm{tha}^{-1}+\mathrm{N}-37.5, \mathrm{P}-30, \mathrm{~K}-45 \mathrm{~kg} \mathrm{ha}^{-1}$

G. fermented cattle manure: $15 \mathrm{tha}^{-1}$

III. Row spacing:

a. Single rows every $30 \mathrm{~cm}$ (seeding rate of $3.5 \mathrm{~kg} \mathrm{ha}^{-1}$ )

b. Single rows every $40 \mathrm{~cm}$ (seeding rate of $3.0 \mathrm{~kg} \mathrm{ha}^{-1}$ ).

Mineral $\mathrm{N}$ fertilization was applied in the form of $34 \%$ ammonium nitrate, $\mathrm{P}$ was given in the form of $46 \%$ granulated triple superphosphate, whereas $\mathrm{K}$ was supplied as $50 \%$ potassium salt. 
"De Dolj" is a Romanian cultivar that matures early and produces large quantities of leaves. It is a very vigorous plant with a good regenerative capacity. It has a medium content of volatile oil and thymol, and a medium to large content of carvacrol.

"Sloneczko", is a Polish cultivar which blooms in semi-wild conditions, with a large ratio of leaves and flowers, at detriment to the leaves; the quantity of which is medium. The plant is strongly branched with small, dark green, lanceolated leaves. Flowers of this variety are light pink to dark purple with partly pink stripes. The volatile oil content is lower than the average, but in contrast, it possesses high mean values for timol and carvacrol [28]

Thyme was grown on Podzolic soil (soil class III) [29]. The soil content of the major nutrients is presented in Table 1.

Table 1. Characteristics of some soil quality parameters before the experiment.

\begin{tabular}{|c|c|c|c|c|c|}
\hline \multirow[b]{2}{*}{ Year } & \multirow[b]{2}{*}{$\begin{array}{c}\mathrm{pH} \\
1 \mathrm{M} \mathrm{KCl}\end{array}$} & \multicolumn{4}{|c|}{ Content of } \\
\hline & & $\begin{array}{c}P \\
\left(\mathrm{mg} \mathrm{kg}^{-1} \text { soil) }\right.\end{array}$ & $\begin{array}{c}\mathrm{K} \\
\left(\mathrm{mg} \mathrm{kg}^{-1} \text { soil) }\right.\end{array}$ & $\begin{array}{c}\mathrm{Mg} \\
\left(\mathrm{mg} \mathrm{kg}^{-1} \text { soil) }\right.\end{array}$ & $\begin{array}{c}\text { Humus } \\
(\%)\end{array}$ \\
\hline 2017 & 6.3 & 137 & 182 & 68 & 1.35 \\
\hline 2018 & 6.1 & 129 & 174 & 63 & 1.33 \\
\hline 2019 & 6.2 & 125 & 170 & 61 & 1.29 \\
\hline
\end{tabular}

The data contained in Table 1 show that in each study year before the establishment of the experiment, the soil had a slightly acidic $\mathrm{pH}$, the content of available nutrients was at a medium level, whereas the humus content ranged between 1.29-1.35\%.

The organic materials used in the experiment were as follows: spent mushroom substrate and fermented cattle manure (dry matter content of 28.4 and $26.1 \%$, respectively), and a $\mathrm{N}$ dry matter content of 26.2 and $22.5 \mathrm{~g} \mathrm{~kg}^{-1}$ (Table 2). The spent mushroom substrate was poorer in carbon organic compounds $\left(363.4 \mathrm{~g} \mathrm{~kg}^{-1} \mathrm{DM}\right)$ as well as in phosphorus and potassium (respectively, 10.7 and $13.8 \mathrm{~g} \mathrm{~kg}^{-1} \mathrm{DM}$ ) relative to manure, in which the carbon content was $415.2 \mathrm{~g} \mathrm{~kg}^{-1} \mathrm{DM}$, the phosphorus content was $13.1 \mathrm{~g} \mathrm{~kg}^{-1} \mathrm{DM}$, and the potassium content was $19.9 \mathrm{~g} \mathrm{~kg}^{-1} \mathrm{DM}$.

Table 2. Characteristics of organic materials used in the experiment (mean for 2017-2019).

\begin{tabular}{cccccc}
\hline & & \multicolumn{4}{c}{$\begin{array}{c}\text { Macronutrient Content } \\
\left.\text { (g kg } \mathbf{~ k}^{-\mathbf{1}} \mathbf{D M}\right)\end{array}$} \\
\cline { 3 - 6 } Organic Material & $\begin{array}{c}\text { Air Dry Matter } \\
\mathbf{( \% )}\end{array}$ & $\mathbf{C}$ & $\mathbf{N}$ & $\mathbf{P}$ & $\mathbf{K}$ \\
\hline Mushroom substrate & 28.4 & 36.4 & 26.2 & 10.7 & 13.8 \\
Farmyard manure & 26.1 & 415.2 & 22.5 & 13.1 & 19.9 \\
\hline
\end{tabular}

Mineral fertilization (both at the recommended rate-treatment $\mathrm{B}$, and at the rates supplementing SMS fertilization-treatments D, E, F) was applied in the spring before sowing the thyme. Spent mushroom substrate and cattle manure were applied at a single dose in the autumn (before autumn ploughing was carried out to cover the fertilizers with the soil). In all treatments $(A-G)$, the previous crop for thyme was white mustard, grown for green manure.

Tillage operations were adapted to the specific agronomy of thyme, the previous crop, and type of fertilization. In all treatments, plough skimming and harrowing were carried out after harvest of the previous crop (white mustard). Subsequently, in the autumn (the first or second 10 days of October) organic fertilization (spent mushroom substrate, manure) was applied and the fertilizers were ploughed into the soil (treatments $C-G$ ). In the control treatment (A) and in treatment $B$, ridge ploughing was performed in the autumn and no other tillage operations were completed until the spring. In the spring, the field was smoothed with a seedbed conditioner and prepared for application of mineral NPK fertilizers (treatments B, D, E, F) and for thyme seeding. 
Thyme seeds were sown directly into the soil in the third 10 days of April. Sowing was carried out using a seed drill with a press wheel. Weed control involved mechanical weed removal in the inter-rows (using a weeder or hand hoe at the 3-5 leaf stage of thyme). No crop protection chemicals were used in the experiment (environmentally friendly agronomic practices).

\subsection{Observations}

Thyme was harvested in the second or third 10 days of August by cutting the herb at a height of about $5 \mathrm{~cm}$ with a sickle bar mower. After cutting, the herb was dried in an air circulation drying oven at a temperature of about $35^{\circ} \mathrm{C}$ and subsequently threshed in a "Warmianka" thresher. The threshed crop was weighed, and the obtained values were converted from $\mathrm{kg}$ for a given plot to $\mathrm{tha}^{-1}$.

\subsection{Study Measurements}

Samples were taken from the obtained herbal material for chemical composition determinations, which included the following:

\subsubsection{Essential Oil}

Determination of essential oil content by the pharmacopoeial method-steam distillation of the herbal material [30]. Steam distillation is carried out by passing dry steam through the plant material, whereby the steam volatile compounds are volatilized, condensed and collected in receivers. The measurements of the distillation time started after the falling of the first drop of distillate. After $2 \mathrm{~h}$ of distillation, the volume of the oil collected into the calibrated tube of apparatus was read. Obtained essential oils were dried over anhydrous sodium sulphate and, after filtration, stored in dark sealed vials at $4{ }^{\circ} \mathrm{C}$ until GC-MS analysis. Tree replicates were carried out. The volume of the extracted essential oils was converted into values per $100 \mathrm{~g}$ of raw material, expressed as weight/volume percentages.

\subsubsection{Total Polyphenolic Content}

Determination of total polyphenolic content by the Folin-Ciocalteu method (expressed as gallic acid (GAE) equivalents). Briefly, $200 \mu \mathrm{L}$ of crude extract ( $1 \mathrm{mg} / \mathrm{mL}$ ) was made up to $3 \mathrm{~mL}$ with distilled water, mixed thoroughly with $0.5 \mathrm{~mL}$ of Folin-Ciocalteu reagent for $3 \mathrm{~min}$, followed by the addition of $2 \mathrm{~mL}$ of $20 \%(w / v)$ sodium carbonate. The mixture was allowed to stand for a further $60 \mathrm{~min}$ in the dark, and the absorbance value was measured at $650 \mathrm{~nm}$. The total phenolic content was calculated from the calibration curve, and the results were expressed as mg of gallic acid equivalent per $g$ dry weight $[31,32]$

\subsubsection{Flavonoid Content}

Determination of flavonoid content using Christ-Müller's method [30]. The flavonoid content was determined spectrophotometrically, after extraction of flavonoids from the raw material, and expressed as quercetin equivalents (QE). This method involves acid hydrolysis of flavonol glycosides, followed by the formation of colored complexes of these flavonoid compounds with $\mathrm{AlCl}_{3}$. Absorbance was measured at $\lambda=425.0 \mathrm{~nm}$ with a Cintra 20 UV-VIS spectrometer (GBC). All solvents (analytical grade) were purchased from. Avantor Performance Materials Poland S.A., Gliwice, Poland.

\subsubsection{2,2-Diphenyl-1-Picrylhydrazyl (DPPH) Content}

The 2,2-diphenyl-1-picrylhydrazyl (DPPH) radical scavenging activity was determined. The determination involved colorimetric measurement of the level of reduction of a known amount of DPPH by the extract of the tested sample. Changes in the content of DPPH radicals were recorded spectrophotometrically after a $10 \mathrm{~min}$ incubation period with the tested extracts, at a wavelength of $517 \mathrm{~nm}$. The determination was made using the method provided by Chen and Ho [33]. 


\subsubsection{Antioxidant Activity}

Determination of antioxidant activity by the ABTS method given by Re et al. [34]. Changes in the concentration of ABTS + cation radicals were determined spectrophotometrically after a $6 \mathrm{~min}$ incubation with the tested extracts. Compounds with antioxidant properties contained in these extracts reduced the concentrations of ABTS $\bullet+$ cation radicals, which were measured as a decrease in the absorbance of the solution at a wavelength of $734 \mathrm{~nm}$.

\subsubsection{Reducing Power of Extracts (FRAP Assay)}

Determination of the reducing power of extracts (FRAP: ferric reducing ability of plasma assay) was conducted according to Benzie and Strain [35]. The stock solutions contained $300 \mathrm{mM}$ acetate buffer $\left(3.1 \mathrm{~g} \mathrm{C}_{2} \mathrm{H}_{3} \mathrm{NaO}_{2}{ }^{-} 3 \mathrm{H}_{2} \mathrm{O}\right.$ and $\left.16 \mathrm{~mL} \mathrm{C}_{2} \mathrm{H}_{4} \mathrm{O}_{2}\right), \mathrm{pH}$ 3.6, $10 \mathrm{mM}$ TPTZ (2,4,6-tripyridyl-s-triazine) solution in $40 \mathrm{mM} \mathrm{HCl}$, and $20 \mathrm{mM} \mathrm{FeCl}_{3} 6 \mathrm{H}_{2} \mathrm{O}$ solution. The fresh working solution was prepared by mixing the TPTZ solution, $\mathrm{FeCl}_{3}$ $6 \mathrm{H}_{2} \mathrm{O}$ solution, and acetate buffer in the ratio of $1: 1: 10$ and it was warmed at $37^{\circ} \mathrm{C}$ for $25 \mathrm{~min}$ before use. The plant extract or reference was allowed to react with the FRAP solution in the dark condition for $30 \mathrm{~min}$. Readings of the colored product (ferrous tripyridyl triazine complex) were then measured at $593 \mathrm{~nm}$. The standard curve was linear between 100 and $1000 \mu \mathrm{M} \mathrm{FeSO}_{4}$. The results are expressed in $\mu \mathrm{M}(\mathrm{Fe}(\mathrm{II}) / \mathrm{g})$ dry mass. Decreased absorbance indicates the ferric reducing power capability of the sample.

\subsection{Statistical Analyses}

Analysis of variance (ANOVA) was used to statistically analyze the results by employing Statgraphics 5.0 software, while Tukey's test was applied to determine HSD (Honest Significant Difference) values at $p<0.05$. The mean for the study period is given in the results tables because the year-to-year differences between the characteristics analyzed were statistically insignificant.

\section{Results}

The total yield of thyme was significantly related to the cultivar factor. Regardless of the other factors, cv. "Słoneczko" produced a higher yield by about $0.14 \mathrm{t} \mathrm{ha}^{-1}(15 \%)$ compared to cv. "De Dolj" (Table 3). The thyme yield exhibited an even stronger relationship with the row spacing used in the experiment. Growing thyme at a row spacing of $40 \mathrm{~cm}$ resulted in an increase in yield in the range of $0.17 \mathrm{t} \mathrm{ha}^{-1}$ (about 18\%), compared to the narrower spacing $(30 \mathrm{~cm})$. The type of fertilization had a less pronounced effect on increasing the thyme yield. Nonetheless, significantly higher yields of the herbal plant were found in treatment B (mineral NPK fertilization) and treatment E (SMS 50\% + NPK $50 \%$ ) relative to the control treatment (A) and treatments C (SMS 100\%) and G (manure). A particularly high efficiency of some fertilization variants (objects B, D, E, and especially F) was recorded in the case of cv. "Słoneczko" cultivated at a row spacing of $40 \mathrm{~cm}$ (yield of air-dry weight of thyme $=2.07-2.12 \mathrm{t} \mathrm{ha}^{-1}$ ). The obtained results demonstrate that SMS can successfully supplement mineral NPK fertilization and be an alternative to manure fertilization in thyme cultivation (Table 3).

The essential oil content in the thyme raw material was significantly dependent on all experimental factors (Table 4). The content of this component in cv. "Słoneczko" was higher by 0.14 percentage points (p.p.) in comparison with cv. "De Dolj". All types of fertilization contributed to a significantly higher content of essential oils in the thyme raw material, relative to the control plots (A), but the following fertilization regimes had the most beneficial effects on essential oil content: SMS applied at 100\% and SMS at 70\% (+30\% NPK) - more essential oil by 1.10 p.p., as well as manure (more essential oil by 1.10 p.p.). The described relationships occurred in both cultivars of thyme. However, the use of $100 \%$ SMS fertilization in the cv. "Słoneczko" increased the content of essential oil by 1.19 p.p. Regardless of the cultivar and type of fertilization, growing thyme at the wider row spacing $(40 \mathrm{~cm})$ resulted in a lower essential oil content by about 0.03 p.p. compared 
to a row spacing of $30 \mathrm{~cm}$. A significant negative interaction was found with respect to essential oil content when cv. "De Dolj" was grown at a row spacing of $40 \mathrm{~cm}$ (essential oil content $=3.25 \%$ ). Moreover, a significant relationship was observed between row spacing and type of fertilization with regard to essential oil content (a row spacing of $30 \mathrm{~cm}$ and SMS fertilization-essential oil content $=3.62 \%$ ).

Table 3. Yield of air-dry weight of thyme $\left(\mathrm{t} \mathrm{ha}^{-1}\right)$.

\begin{tabular}{|c|c|c|c|c|c|c|c|c|c|}
\hline \multirow{2}{*}{ Fertilization } & \multicolumn{3}{|c|}{ Cv. "Słoneczko" } & \multicolumn{3}{|c|}{ Cv. "De Dolj" } & \multicolumn{2}{|c|}{ Mean for Row Spacing } & \multirow{2}{*}{ Mean } \\
\hline & $40 \mathrm{~cm}$ & $30 \mathrm{~cm}$ & Mean & $40 \mathrm{~cm}$ & $30 \mathrm{~cm}$ & Mean & $40 \mathrm{~cm}$ & $30 \mathrm{~cm}$ & \\
\hline A & 0.98 & 0.85 & 0.91 & 0.89 & 0.78 & 0.83 & 0.93 & 0.81 & $0.87^{\mathrm{a}}$ \\
\hline $\mathrm{B}$ & 2.09 & 1.91 & 2.00 & 1.95 & 1.73 & 1.84 & 2.02 & 1.82 & $1.92^{\mathrm{b}}$ \\
\hline $\mathrm{C}$ & 1.95 & 1.82 & 1.88 & 1.80 & 1.75 & 1.77 & 1.87 & 1.78 & $1.82^{\mathrm{c}}$ \\
\hline $\mathrm{D}$ & 2.07 & 1.90 & 1.98 & 1.92 & 1.70 & 1.81 & 1.99 & 1.80 & $1.89^{\mathrm{d}}$ \\
\hline $\mathrm{E}$ & 2.08 & 1.89 & 1.98 & 1.99 & 1.72 & 1.85 & 2.03 & 1.80 & $1.91^{\mathrm{b}}$ \\
\hline $\mathrm{F}$ & 2.12 & 1.86 & 1.99 & 1.88 & 1.71 & 1.79 & 2.00 & 1.78 & $1.89^{\mathrm{d}}$ \\
\hline G & 1.92 & 1.81 & 1.86 & 1.84 & 1.69 & 1.76 & 1.88 & 1.78 & $1.83^{c}$ \\
\hline Mean & 1.03 & 0.86 & $0.94^{\mathrm{a}}$ & 0.89 & 0.72 & $0.80^{b}$ & $0.96^{\mathrm{a}}$ & $0.79^{b}$ & - \\
\hline $\operatorname{HSD}_{(0.05)}$ & $\begin{array}{l}\text { for } \mathrm{cu} \\
\text { row } \mathrm{s}\end{array}$ & $\begin{array}{l}\text { rs- } 0 . \\
\text { g- }-n \\
\text { tilizat }\end{array}$ & for $\mathrm{f}$ & catio & $\begin{array}{l}089 ; \\
\operatorname{tar} \times\end{array}$ & ow s] & $\begin{array}{l}\text { g- } 0.08 \\
- \text { n.s.; fo } \\
\text { pacing }\end{array}$ & $\begin{array}{l}\text { teractio } \\
\text { tion rov } \\
\text { zation }\end{array}$ & $\begin{array}{l}\text { ltivar } \times \\
\operatorname{acing} \times\end{array}$ \\
\hline
\end{tabular}

A. control treatment; B. mineral NPK fertilization (100\%); C. spent mushroom substrate (SMS) (100\%); D. SMS (70\%) + NPK (30\%); E. SMS (50\%) + NPK (50\%); F. SMS (30\%) + NPK (70\%); G. manure; means for the main effects of the experiment marked with different letters $\left({ }^{a}, b, \ldots\right)$ in the last column and the last row in the table-differ significantly; there were no significant interactions regarding the thyme yield with regard to the experimental factors, n.s.- not significant.

Table 4. Essential oil content in thyme raw material (\%DM).

\begin{tabular}{|c|c|c|c|c|c|c|c|c|c|}
\hline \multirow{2}{*}{ Fertilization } & \multicolumn{3}{|c|}{ Cv. "Słoneczko" } & \multicolumn{3}{|c|}{ Cv. "De Dolj" } & \multicolumn{2}{|c|}{ Mean for Row Spacing } & \multirow{2}{*}{ Mean } \\
\hline & $40 \mathrm{~cm}$ & $30 \mathrm{~cm}$ & Mean & $40 \mathrm{~cm}$ & $30 \mathrm{~cm}$ & Mean & $40 \mathrm{~cm}$ & $30 \mathrm{~cm}$ & \\
\hline A & 2.53 & 2.53 & 2.53 & 2.33 & 2.33 & 2.33 & 2.43 & 2.43 & $2.43^{\mathrm{a}}$ \\
\hline $\mathrm{B}$ & 3.67 & 3.73 & 3.69 & 3.33 & 3.33 & 3.33 & 3.50 & 3.53 & $3.51^{\mathrm{b}}$ \\
\hline $\mathrm{C}$ & 3.57 & 3.86 & 3.72 & 3.29 & 3.38 & 3.34 & 3.43 & $3.62 b c$ & $3.53^{b}$ \\
\hline $\mathrm{D}$ & 3.48 & 3.48 & 3.48 & 3.48 & 3.67 & 3.58 & 3.48 & 3.58 & $3.53^{\mathrm{b}}$ \\
\hline $\mathrm{E}$ & 3.38 & 3.53 & 3.45 & 3.48 & 3.43 & 3.46 & 3.43 & 3.48 & $3.46^{\mathrm{b}}$ \\
\hline $\mathrm{F}$ & 3.86 & 3.33 & 3.60 & 3.29 & 3.48 & 3.39 & 3.58 & 3.41 & $3.49^{b}$ \\
\hline G & 3.48 & 3.48 & 3.48 & 3.57 & 3.57 & 3.57 & 3.53 & 3.53 & $3.53^{b}$ \\
\hline Mean & 3.42 & 3.42 & $3.42^{\mathrm{a}}$ & $3.25 \mathrm{ac}$ & 3.31 & $3.28^{b}$ & $3.34^{\mathrm{a}}$ & $3.37^{\mathrm{b}}$ & - \\
\hline $\operatorname{HSD}_{(0.05)}$ & \multicolumn{9}{|c|}{$\begin{array}{l}\text { for cultivars- }-0.01 \text {; for fertilization }-0.03 \text {; for row spacing }-0.01 \text {; for interaction cultivar } \times \\
\text { row spacing- } 0.02 \text {; for interaction cultivar } \times \text { fertilization }-0.04 \text {; for interaction row spacing } \\
\quad \times \text { fertilization }-0.04 \text {; for interaction cultivar } \times \text { row spacing } \times \text { fertilization }-\mathrm{n} \text {.s. }\end{array}$} \\
\hline
\end{tabular}

A. control treatment; B. mineral NPK fertilization (100\%); C. SMS (100\%); D. SMS (70\%) + NPK (30\%); E. SMS (50\%) + NPK (50\%); F. SMS (30\%) + NPK (70\%); G. manure; means for the main effects of the experiment marked with different letters $(a, b, \ldots)$ in the last column and the last row in the table-differ significantly; the significance of the interaction of the experimental factors was marked as follows: ac $=$ cultivar $\times$ row spacing; $\mathrm{bc}=$ fertilization $\times$ row spacing, n.s.- not significant.

The thyme cultivar "Słoneczko" was characterized by a significantly higher total polyphenols value in the herbal material in comparison with cv. "De Dolj" (by about 9\%). Total polyphenol level was significantly affected by the type of fertilization. Significantly, the lowest levels of polyphenols were found in the raw material from the control plots (without fertilization). SMS fertilization (100\% rate) and SMS (70\% rate) supplemented with NPK fertilization ( $30 \%$ rate) had the greatest beneficial effect on the content of this component, with this effect being significant. Such a relationship occurred both for the averaged values of two cultivars of thyme, and for the cultivars ("Słoneczko", "De Dolj") considered separately. Fertilization with 100\% SMS and fertilization with 70\% SMS + 30\% NPK resulted in a 2.3-fold increase and 1.7-fold increase, respectively, in the total polyphenols content in thyme raw material-relative to the control plots. 
The other fertilization treatments impacted the polyphenol content to a similar degree. The narrower row spacing $(30 \mathrm{~cm})$ proved to be significantly more beneficial for the polyphenol content in the raw material, but the above relationship was predominantly determined by the differences in the polyphenol content in cv. "Słoneczko" (content of polyphenols greater by $15.77 \mathrm{mg}$ GAE $100 \mathrm{~g}^{-1}$ ). Cv. "De Dolj" was characterized by an identical polyphenol content both in the case of wide-row cultivation $(40 \mathrm{~cm})$ and the narrower row spacing $(30 \mathrm{~cm})$. A significant interaction was found between cv. "Słoneczko" and SMS fertilization (polyphenol content $=1688.26 \mathrm{mg} \mathrm{GAE} 100 \mathrm{~g}^{-1}$ ). A row spacing of $30 \mathrm{~cm}$ with SMS fertilization was also shown to exhibit a significant interaction. Significantly the highest polyphenol content was recorded for cv. "Słoneczko" grown at the narrower row spacing $(30 \mathrm{~cm})$, with application of SMS fertilization $\left(1714.13 \mathrm{mg}\right.$ GAE $\left.100 \mathrm{~g}^{-1}\right)$ (Table 5).

Table 5. Total polyphenols content in thyme raw material (mg GAE $100 \mathrm{~g}^{-1}$ ).

\begin{tabular}{|c|c|c|c|c|c|c|c|c|c|}
\hline \multirow{2}{*}{ Fertilization } & \multicolumn{3}{|c|}{ Cv. "Słoneczko" } & \multicolumn{3}{|c|}{ Cv. “De Dolj” } & \multicolumn{2}{|c|}{ Mean for Row Spacing } & \multirow{2}{*}{ Mean } \\
\hline & $40 \mathrm{~cm}$ & $30 \mathrm{~cm}$ & Mean & $40 \mathrm{~cm}$ & $30 \mathrm{~cm}$ & Mean & $40 \mathrm{~cm}$ & $30 \mathrm{~cm}$ & \\
\hline A & 624.26 & 631.16 & 627.71 & 676.00 & 589.77 & 632.89 & 650.13 & 610.47 & $630.30^{a}$ \\
\hline B & 910.52 & 934.67 & 922.60 & 827.75 & 838.09 & 832.92 & 869.14 & 886.38 & $877.76^{\mathrm{b}}$ \\
\hline $\mathrm{C}$ & 1662.39 & $1714.13 \mathrm{abc}$ & $1688.26 \mathrm{ab}$ & 1238.17 & 1296.81 & 1267.49 & 1450.28 & $1505.47 \mathrm{bc}$ & $1477.88^{\mathrm{c}}$ \\
\hline $\mathrm{D}$ & 1093.32 & 1114.01 & 1103.67 & 1013.99 & 1031.24 & 1022.62 & 1053.66 & 1072.63 & $1063.14^{\mathrm{d}}$ \\
\hline $\mathrm{E}$ & 879.48 & 903.63 & 891.56 & 769.12 & 793.26 & 781.19 & 824.30 & 848.44 & $836.37^{b}$ \\
\hline $\mathrm{F}$ & 727.73 & 731.18 & 729.45 & 838.09 & 831.20 & 834.65 & 782.91 & 781.19 & $782.05^{b}$ \\
\hline G & 724.28 & 703.59 & 713.93 & 734.63 & 717.38 & 726.00 & 729.45 & 710.48 & $719.97^{b}$ \\
\hline Mean & 946.00 & $961.77 \mathrm{ac}$ & $953.88^{a}$ & 871.11 & 871.11 & $871.11^{b}$ & $908.55^{a}$ & $916.44^{b}$ & - \\
\hline $\operatorname{HSD}_{(0.05)}$ & \multicolumn{9}{|c|}{$\begin{array}{l}\text { for cultivars-7.49; for fertilization-61.38; for row spacing }-7.53 \text {; for interaction cultivar } \times \text { row spacing-14.04; for } \\
\text { interaction cultivar } \times \text { fertilization }-34.70 \text {; for interaction row spacing } \times \text { fertilization }-34.68 \text {; for interaction cultivar } \\
\times \text { row spacing } \times \text { fertilization }-52.06 \text {. }\end{array}$} \\
\hline
\end{tabular}

A. control treatment; B. mineral NPK fertilization (100\%); C. SMS (100\%); D. SMS (70\%) + NPK (30\%); E. SMS (50\%) + NPK (50\%); F. SMS $(30 \%)+$ NPK $(70 \%)$; G. manure; means for the main effects of the experiment marked with different letters $\left({ }^{a}, b, \ldots\right)$ in the last column and the last row in the table-differ significantly; the significance of the interaction of the experimental factors was marked as follows: $\mathrm{ab}=$ cultivar $\times$ fertilization; $\mathrm{ac}=$ cultivar $\times$ row spacing; $\mathrm{bc}=$ fertilization $\times$ row spacing; $\mathrm{abc}=$ cultivar $\times$ fertilization $\times$ row spacing, n.s.-not significant.

The thyme raw material of cv. "Słoneczko" showed a significantly higher flavonoid content compared to cv. "De Dolj" (on average by 11\%), regardless of the other experimental factors. The type of fertilization significantly modified the flavonoid content, with SMS applied a rate of $100 \%$ and at a rate of $70 \%+$ NPK ( $30 \%$ rate) having the most beneficial effect on it. The use of $100 \%$ SMS fertilization resulted in a more than three-fold increase in flavonoid content in the thyme raw material. The presented relationships concerned both cultivars of thyme and both row spacings-as well as the average values of the flavonoids content in the raw material cv. "Słoneczko" and cv. "De Dolj". The other SMS + NPK fertilization combinations $(50 \%+50 \%$ rate and $30 \%+70 \%$ rate) also had a significantly beneficial impact on the flavonoid content in comparison with $100 \%$ mineral NPK fertilization, manure fertilization, and the control treatment. Row spacing did not significantly influence the content of the component in question. However, a significant interaction was found between the narrower row spacing and SMS fertilization alone (57.397 mg CA $100 \mathrm{~g}^{-1}$ ). The statistically proven highest flavonoid content in the thyme raw material $\left(64.555 \mathrm{mg} \mathrm{CA} 100 \mathrm{~g}^{-1}\right)$ was recorded when cv. "Słoneczko" was grown at a row spacing of $30 \mathrm{~cm}$ and a 100\% SMS fertilization regime was applied (Table 6).

A very important quality characteristic of thyme herbal material is its ability to scavenge DPPH free radicals. When we consider this ability in terms of the cultivar factor, we note that the radical scavenging activity was significantly more beneficial (by about $7 \%$ ) in the case of $\mathrm{cv}$. "Słoneczko". The effect of row spacing on the characteristic in 
question proved to be statistically insignificant. However, there was a trend towards a more favorable DPPH value when cultivating cv. "De Dolj" at a row spacing of $30 \mathrm{~cm}$.

Table 6. Flavonoid content in thyme raw material (mg CA $100 \mathrm{~g}^{-1}$ ).

\begin{tabular}{|c|c|c|c|c|c|c|c|c|c|}
\hline \multirow{2}{*}{ Fertilization } & \multicolumn{3}{|c|}{ Cv. "Słoneczko" } & \multicolumn{3}{|c|}{ Cv. “De Dolj” } & \multicolumn{2}{|c|}{ Mean for Row Spacing } & \multirow{2}{*}{ Mean } \\
\hline & $40 \mathrm{~cm}$ & $30 \mathrm{~cm}$ & Mean & $40 \mathrm{~cm}$ & $30 \mathrm{~cm}$ & Mean & $40 \mathrm{~cm}$ & $30 \mathrm{~cm}$ & \\
\hline $\mathrm{A}$ & 17.631 & 17.959 & 17.795 & 19.218 & 15.868 & 17.543 & 18.425 & 16.913 & $17.669^{a}$ \\
\hline B & 21.737 & 22.577 & 22.157 & 27.194 & 25.095 & 26.144 & 24.465 & 23.836 & $24.150^{\mathrm{a}}$ \\
\hline $\mathrm{C}$ & 58.258 & $64.555 \mathrm{abc}$ & 61.407 & 45.790 & 50.240 & 48.015 & 52.024 & $57.397 \mathrm{bc}$ & $54.711^{\mathrm{b}}$ \\
\hline $\mathrm{D}$ & 43.019 & 42.180 & 42.599 & 37.269 & 37.689 & 37.479 & 40.144 & 39.934 & $40.039^{b}$ \\
\hline $\mathrm{E}$ & 35.170 & 36.009 & 35.590 & 31.517 & 33.071 & 32.294 & 33.343 & 34.540 & $33.942^{c}$ \\
\hline $\mathrm{F}$ & 36.429 & 34.750 & 35.590 & 27.614 & 28.662 & 28.138 & 32.021 & 31.706 & $31.864^{c}$ \\
\hline $\mathrm{G}$ & 22.996 & 20.066 & 21.531 & 23.835 & 20.477 & 22.156 & 23.416 & 20.272 & $21.844^{\mathrm{a}}$ \\
\hline Mean & 33.606 & 34.014 & $33.810^{a}$ & 30.348 & 30.157 & $30.253^{b}$ & $31.977^{\mathrm{a}}$ & $32.085^{a}$ & - \\
\hline $\operatorname{HSD}_{(0.05)}$ & \multicolumn{9}{|c|}{$\begin{array}{l}\text { for cultivars-0.58; for fertilization-8.57; for row spacing-n.s.; for interaction cultivar } \times \text { row spacing-n.s.; for } \\
\text { interaction cultivar } \times \text { fertilization-2.59; for interaction row spacing } \times \text { fertilization-2.57; for interaction cultivar } \times \\
\text { row spacing } \times \text { fertilization }-3.86 .\end{array}$} \\
\hline
\end{tabular}

A. control treatment; B. mineral NPK fertilization (100\%); C. SMS (100\%); D. SMS (70\%) + NPK (30\%); E. SMS (50\%) + NPK (50\%); F. SMS $(30 \%)+$ NPK (70\%); G. manure; means for the main effects of the experiment marked with different letters $(a, b, \ldots)$ in the last column and the last row in the table-differ significantly; the significance of the interaction of the experimental factors was marked as follows: $\mathrm{bc}=$ fertilization $\times$ row spacing; $\mathrm{abc}=$ cultivar $\times$ fertilization $\times$ row spacing, n.s. - not significant.

The type of fertilization, on the other hand, contributed to a significant modification of this trait. The absence of fertilization (control treatment A) and mineral NPK fertilization (treatment B) significantly caused the lowest DPPH free radical scavenging activity relative to the other experimental treatments. However, SMS fertilization of thyme at a $100 \%$ rate and at a rate of $70 \%$ SMS $+30 \%$ NPK had significantly the most beneficial effect on this quality parameter of the raw material. The above-mentioned fertilization variatoins resulted in a higher, respectively, 3.6 times and 2.5 times, DPPH value in relation to the control (A). Interestingly, 100\% NPK fertilization used in cv. "Słoneczko", reduced the DPPH radical scavenging activity (by approximately $27 \%$ ) compared with the control (without fertilization). The other fertilization combinations with different proportions of SMS and mineral NPK fertilization ( $50 \%+50 \%$ and $30 \%+70 \%)$ also had a significantly more beneficial impact on this parameter than manure fertilization and 100\% NPK fertilization. Therefore, it is worth noting that the use of SMS in thyme fertilization positively affects the herbal material by stimulating its DPPH radical scavenging activity. A statistically significant positive interaction was found between cv. "Słoneczko" and SMS fertilizationDPPH radical scavenging activity $=68.227 \mu \mathrm{M} \mathrm{TE} \mathrm{g}^{-1}$. A significant positive relationship was also noted between the narrower row spacing and fertilization of the thyme plantation with SMS alone-in such case, DPPH radical scavenging activity of the herbal material was $60.360 \mu \mathrm{M} \mathrm{TE} \mathrm{g}^{-1}$ (Table 7).

When considering the data contained in Table 8, we notice that-regardless of the other experimental factors-the raw material of cv. "Słoneczko" was characterized by significantly higher antioxidant activity relative (on average by about $4 \%$ ) to cv. "De Dolj". Application of SMS (both in pure form and in combination with NPK fertilization) and manure fertilization resulted in a statistically proven higher level of antioxidant activity of the raw material in comparison with mineral NPK fertilization and the control treatment (without fertilization). SMS fertilization (100\% rate) and SMS supplemented with a $30 \%$ rate of NPK caused a particularly high increase (of the magnitude of about four times and 2.8 times) in the antioxidant properties of the thyme raw material. The above-mentioned fertilization treatments contributed to a significant improvement in the quality characteristic in question, both for cv. "Słoneczko" and cv. "De Dolj" (4\% on average). Irrespective of fertilization application, the narrower row spacing of the thyme resulted in a significantly higher level of antioxidant activity of the herbal material, both in 
the case of cv. "Słoneczko" and cv. "De Dolj". Thus, this effect was observed regardless of the cultivar. Furthermore, a significant interaction was observed between the fertilization regime and the row spacing of thyme (the most beneficial antioxidant property $-26.44 \mu \mathrm{M}$ $\mathrm{TE}^{-1}$ — was found for the fertilization treatments where the plots were fertilized with SMS alone and at a row spacing of $30 \mathrm{~cm}$ (Table 8).

Table 7. DPPH radical scavenging activity determined in thyme raw material $\left(\mu \mathrm{M} \mathrm{TE} \mathrm{g}^{-1}\right)$.

\begin{tabular}{|c|c|c|c|c|c|c|c|c|c|}
\hline \multirow{2}{*}{ Fertilization } & \multicolumn{3}{|c|}{ Cv. "Słoneczko" } & \multicolumn{3}{|c|}{ Cv. “De Dolj” } & \multicolumn{2}{|c|}{ Mean for Row Spacing } & \multirow{2}{*}{ Mean } \\
\hline & $40 \mathrm{~cm}$ & $30 \mathrm{~cm}$ & Mean & $40 \mathrm{~cm}$ & $30 \mathrm{~cm}$ & Mean & $40 \mathrm{~cm}$ & $30 \mathrm{~cm}$ & \\
\hline A & 16.137 & 15.526 & 15.832 & 18.092 & 15.068 & 16.580 & 17.115 & 15.297 & $16.206^{a}$ \\
\hline $\mathrm{B}$ & 11.860 & 11.401 & 11.631 & 24.539 & 23.775 & 24.157 & 18.199 & 17.588 & $17.894^{\mathrm{a}}$ \\
\hline $\mathrm{C}$ & 67.616 & 68.838 & $68.227 \mathrm{ab}$ & 48.827 & 51.882 & 50.354 & 58.221 & $60.360 \mathrm{bc}$ & $59.291^{b}$ \\
\hline $\mathrm{D}$ & 40.119 & 45.619 & 42.869 & 35.995 & 43.633 & 39.814 & 38.057 & 44.626 & $41.341^{\mathrm{c}}$ \\
\hline $\mathrm{E}$ & 37.370 & 35.843 & 36.606 & 36.301 & 33.398 & 34.850 & 36.835 & 34.621 & $35.728^{\mathrm{d}}$ \\
\hline $\mathrm{F}$ & 32.635 & 33.857 & 33.246 & 27.899 & 28.663 & 28.281 & 30.267 & 31.260 & $30.764^{\mathrm{d}}$ \\
\hline G & 26.677 & 24.691 & 25.684 & 23.928 & 23.194 & 23.561 & 25.302 & 23.943 & $24.623^{\mathrm{e}}$ \\
\hline Mean & 33.202 & 33.682 & $33.442^{a}$ & 30.797 & 31.373 & $31.085^{b}$ & $32.000^{a}$ & $32.528^{a}$ & - \\
\hline $\operatorname{HSD}_{(0.05)}$ & $\begin{array}{l}\text { for cult } \\
\text { interacti }\end{array}$ & -0.97 & $\begin{array}{l}\text { tilizati } \\
\text { ization }\end{array}$ & $\begin{array}{l}13 \text {; for } \\
\text {; for ir } \\
\text { row }\end{array}$ & $\begin{array}{l}\text { pacin } \\
\text { on ro } \\
\times \mathrm{fe}\end{array}$ & $\begin{array}{l}\text {; for in } \\
\text { ing } \times \\
\text { tion-r }\end{array}$ & $\begin{array}{l}\text { tion cult } \\
\text { zation- }\end{array}$ & $\begin{array}{l}\text { row spa } \\
\text { or interac }\end{array}$ & $\begin{array}{l}\text {-n.s.; for } \\
\text { ultivar } \times\end{array}$ \\
\hline
\end{tabular}

A. control treatment; B. mineral NPK fertilization (100\%); C. SMS (100\%); D. SMS (70\%) + NPK (30\%); E. SMS (50\%) + NPK (50\%); F. SMS $(30 \%)+$ NPK $(70 \%)$; G. manure; Means for the main effects of the experiment marked with different letters $(\mathrm{a}, \mathrm{b}, \ldots)$ in the last column and the last row in the table-differ significantly; The significance of the interaction of the experimental factors was marked as follows: $a b=$ cultivar $\times$ fertilization; $b c=$ fertilization $\times$ row spacing. DPPH: 2,2-diphenyl-1-picrylhydrazyl, n.s. - not significant.

Table 8. ORAC (oxygen radical absorbance capacity) antioxidant activity determined in thyme raw material $\left(\mu \mathrm{M} \mathrm{TE} \mathrm{g}^{-1}\right)$.

\begin{tabular}{|c|c|c|c|c|c|c|c|c|c|}
\hline \multirow{2}{*}{ Fertilization } & \multicolumn{3}{|c|}{ Cv. "Słoneczko" } & \multicolumn{3}{|c|}{ Cv. "De Dolj" } & \multicolumn{2}{|c|}{ Mean for Row Spacing } & \multirow{2}{*}{ Mean } \\
\hline & $40 \mathrm{~cm}$ & $30 \mathrm{~cm}$ & Mean & $40 \mathrm{~cm}$ & $30 \mathrm{~cm}$ & Mean & $40 \mathrm{~cm}$ & $30 \mathrm{~cm}$ & \\
\hline $\mathrm{A}$ & 5.90 & 5.67 & 5.78 & 6.64 & 5.49 & 6.07 & 6.27 & 5.58 & $5.92^{\mathrm{a}}$ \\
\hline B & 4.26 & 4.09 & 4.18 & 9.35 & 9.05 & 9.20 & 6.81 & 6.57 & $6.69^{a}$ \\
\hline $\mathrm{C}$ & 28.98 & 30.20 & 29.59 & 20.35 & 22.68 & 21.52 & 24.67 & $26.44 \mathrm{bc}$ & $25.55^{b}$ \\
\hline D & 16.27 & 19.91 & 18.09 & 14.56 & 17.72 & 16.14 & 15.41 & 18.81 & $17.11^{\mathrm{c}}$ \\
\hline $\mathrm{E}$ & 15.13 & 14.50 & 14.82 & 14.69 & 13.49 & 14.09 & 14.91 & 14.00 & $14.45^{\mathrm{d}}$ \\
\hline $\mathrm{F}$ & 10.19 & 9.41 & 9.80 & 9.11 & 8.82 & 8.97 & 9.65 & 9.12 & $9.38^{\mathrm{e}}$ \\
\hline G & 12.53 & 13.01 & 12.77 & 10.67 & 10.97 & 10.82 & 11.60 & 11.99 & $11.79^{\mathrm{f}}$ \\
\hline Mean & 13.32 & 13.83 & $13.57^{\mathrm{a}}$ & 12.20 & 12.60 & $12.40^{b}$ & $12.76^{\mathrm{a}}$ & $13.22^{b}$ & - \\
\hline $\operatorname{HSD}_{(0.05)}$ & $\begin{array}{l}\text { for } \mathrm{c} \\
\text { row s }\end{array}$ & tiliza & for $f$ & 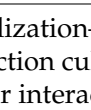 & 69. & 人 10 & $\begin{array}{l}\text {-0.39 } \\
1.78 ; \text { fo } \\
\text { pacing }\end{array}$ & $\begin{array}{l}\text { teraction } \\
\text { action ro } \\
\text { lization- }\end{array}$ & $\begin{array}{l}\text { tivar } \times \\
\operatorname{acing} \times\end{array}$ \\
\hline
\end{tabular}

A. control treatment; B. mineral NPK fertilization (100\%); C. SMS (100\%); D. SMS (70\%) + NPK (30\%); E. SMS $(50 \%)+$ NPK $(50 \%)$; F. SMS $(30 \%)+$ NPK $(70 \%)$; G. manure; means for the main effects of the experiment marked with different letters $\left({ }^{\mathrm{a}}, \mathrm{b}, \ldots\right)$ in the last column and the last row in the table-differ significantly; the significance of the interaction of the experimental factors was marked as follows: $b c=$ fertilization $\times$ row spacing, n.s. - not significant.

The reducing power of extracts (FRAP—ferric reducing ability of plasma) was significantly more beneficial (by $2.449 \mu \mathrm{M} \mathrm{TE} \mathrm{g}^{-1}$ ) in the case of cv. "Słoneczko". The type of fertilization (SMS, SMS + NPK, manure) had significant effect on the increase in reducing power of the extracts compared to the control treatment and object B (NPK fertilization). The 100\% SMS fertilization treatment (treatment C) and the 70\% SMS + 30\% NPK treatment (treatment D) contributed to the highest increase in the FRAP reducing power of extracts, respectively, by 27.512 and $26.873 \mu \mathrm{M} \mathrm{TE} \cdot \mathrm{g}^{-1}$, relative to the control (A). The row spacing of thyme did not significantly influence this characteristic, but a trend towards the increased reducing power of extracts should be noted in the raw material coming from the treatments with the narrow row spacing $(30 \mathrm{~cm})$-both in the case of a cv. "Słoneczko" and cv. "De 
Dolj". Significantly, the highest reducing power of extracts $\left(49.493 \mu \mathrm{M} \mathrm{TE} \mathrm{g}^{-1}\right)$ was found in the treatment where cv. "Słoneczko" crops were fertilized with 100\% SMS. Regardless of the cultivar, significantly the highest reducing power of extracts was obtained for the narrow row spacing $(30 \mathrm{~cm})$ and application of $100 \%$ SMS $\left(41.212 \mu \mathrm{M} \mathrm{TE}^{-1}\right)($ Table 9$)$.

Table 9. Reducing power of extracts (FRAP) determined in thyme raw material $\left(\mu \mathrm{M} \mathrm{TE} \mathrm{g}^{-1}\right)$.

\begin{tabular}{|c|c|c|c|c|c|c|c|c|c|}
\hline \multirow{2}{*}{ Fertilization } & \multicolumn{3}{|c|}{ Cv. “Słoneczko" } & \multicolumn{3}{|c|}{ Cv. “De Dolj” } & \multicolumn{2}{|c|}{ Mean for Row Spacing } & \multirow{2}{*}{ Mean } \\
\hline & $40 \mathrm{~cm}$ & $30 \mathrm{~cm}$ & Mean & $40 \mathrm{~cm}$ & $30 \mathrm{~cm}$ & Mean & $40 \mathrm{~cm}$ & $30 \mathrm{~cm}$ & \\
\hline $\mathrm{A}$ & 13.577 & 11.860 & 12.719 & 13.483 & 10.561 & 12.022 & 13.530 & 11.211 & $12.370^{a}$ \\
\hline B & 6.616 & 6.131 & 6.373 & 20.049 & 19.240 & 19.645 & 13.333 & 12.685 & $13.009^{\mathrm{a}}$ \\
\hline $\mathrm{C}$ & 48.733 & 50.253 & $49.493 \mathrm{ab}$ & 28.371 & 32.170 & 30.271 & 38.552 & $41,212 b c$ & $39.882^{b}$ \\
\hline $\mathrm{D}$ & 30.126 & 28.227 & 29.176 & 28,796 & 25.188 & 26.992 & 29.461 & 26.707 & $28.084^{c}$ \\
\hline $\mathrm{E}$ & 22.315 & 20.211 & 21.263 & 19.402 & 18.625 & 19.013 & 20.858 & 19.418 & $20.138^{d}$ \\
\hline $\mathrm{F}$ & 17.545 & 24.382 & 20.964 & 12.417 & 21.913 & 17.165 & 14.981 & 23.148 & $19.064^{\mathrm{d}}$ \\
\hline G & 28.627 & 29.922 & 29.274 & 23.610 & 24.419 & 24.014 & 26.118 & 27.170 & $26.644^{\mathrm{c}}$ \\
\hline Mean & 23.934 & 24.427 & $24.180^{a}$ & 20.875 & 21.731 & $21.303^{b}$ & $22.405^{a}$ & $23.079^{a}$ & - \\
\hline $\operatorname{HSD}_{(0.05)}$ & $\begin{array}{l}\text { for cult } \\
\text { interacti }\end{array}$ & -0.81 & $\begin{array}{l}\text { tilizati } \\
\text { ization }\end{array}$ & $\begin{array}{l}23 \text {; for } \\
\text {; for ir } \\
\text { row }\end{array}$ & $\begin{array}{l}\text { pacin } \\
\text { on ro } \\
5 \times \mathrm{fe}\end{array}$ & $\begin{array}{l}; \text { for in } \\
\text { ing } \times f \\
\text { tion }-n\end{array}$ & $\begin{array}{l}\text { tion cult } \\
\text { zation- }\end{array}$ & $\begin{array}{l}\text { row spa } \\
\text { r intera }\end{array}$ & $\begin{array}{l}\text {-n.s.; for } \\
\text { ultivar } \times\end{array}$ \\
\hline
\end{tabular}

A. control treatment; B. mineral NPK fertilization (100\%); C. SMS (100\%); D. SMS (70\%) + NPK (30\%); E. SMS (50\%) + NPK (50\%); F. SMS $(30 \%)+$ NPK $(70 \%)$; G. manure; means for the main effects of the experiment marked with different letters $(\mathrm{a}, \mathrm{b}, \ldots)$ in the last column and the last row in the table-differ significantly; the significance of the interaction of the experimental factors was marked as follows: $\mathrm{ab}=$ cultivar $\times$ fertilization; $\mathrm{bc}=$ fertilization $\times$ row spacing. FRAP: ferric reducing ability of plasma, n.s. - not significant.

\section{Discussion}

\subsection{Influence of the Varietal Factor on the Productivity and Quality of Thyme}

The results of this research and the results of other studies reveal that selection of an appropriate cultivar is an important factor affecting the yield and quality of herbal plants $[3,25,26]$. Selecting native cultivars that are well adapted to local soil and climatic conditions, yields the best results. In the present study, the Polish thyme cultivar "Słoneczko" showed a statistically significantly higher yield weight and more favorable quality parameters for all characteristics determined than the foreign cultivar "De Dolj". In turn, other studies show [29] have shown that the "De Dolj" cultivar is characterized by a high yielding and quality of raw material, if grown in its country of origin (Romania) or in similar agro-climatic conditions.

\subsection{Effect of SMS Fertilization on the Yield and Quality of Thyme Raw Material}

In the literature related to this subject, there are a few similar studies regarding the effect of SMS on the productivity of thyme or other herbal plants. Scientific articles mainly address the impact of SMS on soil properties. There are almost no scientific reports that have dealt with the impact of SMS fertilization on the antioxidant properties of herbal materials or vegetable raw materials. We found scientific reports that demonstrate the positive effect of SMS on the productivity of tomato [36-38], rice [11,39], cucumber, cauliflower, spinach, broccoli, or pepper [37,40], as well as on increasing the grain yield of wheat [18] and other plants [21,41,42].

The results obtained in the present study show that quality of thyme raw material was affected to a greater degree by SMS than the yield quantity was (since the highest yields were obtained in the case of mineral NPK fertilization and 50\% SMS + 50\% NPK fertilization). SMS fertilization was found to have a significant influence on the content of essential oil content, polyphenols, and flavonoids as well as on the DPPH free radical scavenging activity and ORAC (oxygen radical absorbance capacity) antioxidant activity determined in the thyme raw material. A study by Kwiatkowski et al. [8] revealed that SMS (at a 100\% rate) - applied for chamomile fertilization-also produced lower yieldincreasing effects than $50 \%$ SMS + 50\% NPK fertilization. Similarly to the present study, a 
$100 \%$ rate of SMS significantly positively influenced the quality traits of chamomile raw material, such as the essential oil, flavonoid, and phenolic acid content, as well as the antioxidant properties expressed through the DPPH radical scavenging activity and ORAC antioxidant activity. The impact of a $100 \%$ rate of SMS and a $50 \%$ rate of SMS $+50 \%$ NPK was at a similar level (it was significantly higher than in the case of $100 \%$ NPK fertilization and manure fertilization) [8]. Positive effects of SMS on chamomile yield have also been reported by Afagh et al. [43].

The results of this research regarding the positive impact of SMS on the healthenhancing properties of thyme raw material are promising. Herbal materials, being important sources of compounds with antioxidant properties, are treated as natural additives to food products. This can be of great importance in neutralizing free radicals [8,44]. In herbal plants, the main antioxidant role is ascribed to essential oils and phenolic compounds $[45,46]$. Free radicals are the beginning of the development of many lifestyle diseases, such as: diabetes, atherosclerosis, Alzheimer's disease, and Parkinson's disease $[47,48]$. Hence, it is important for the content of natural antioxidants in herbal materials to be influenced as early as at the stage of agronomic operations (fertilization). We need to select the type of fertilization that will most likely contribute to the highest content of natural antioxidants in the herbal raw material, in addition to the content of other compounds that exhibit health-promoting effects on humans and animals. This is confirmed by the results of the study discussed in this paper in relation to the example of SMS fertilization of thyme. Dunbar et al. [49] also proved SMS to have a beneficial effect on the properties of tomatoes through improvements in their firmness and ascorbic acid content. Kwiatkowski et al. [8] and Afagh et al. [43], in turn, found an increased essential oil content in chamomile raw material, as affected by SMS fertilization. Ashrafi et al. [38] obtained more favorable quality and health-promoting parameters of tomatoes under the influence of SMS fertilization.

\subsection{Effect of SMS Fertilization on Soil Quality-The Impact of Soil Substrate on the Size and Quality of the Crops}

These very beneficial effects of SMS on the quality and antioxidant properties of herbal material are due to, among other factors, the chemical composition of this fertilizer. The obtained study results regarding the chemical composition of SMS, relative to the composition of manure, are similar to the findings obtained by other studies conducted by Gerrits [50] and Kwiatkowski et al. [8]. A great advantage of SMS relates to its narrow $\mathrm{C}: \mathrm{N}$ ratio (which is 13.8:1.0). In terms of fertilizer value, this is highly favorable, because this indicates the predominance of mineralization of organic nitrogen compounds over their synthesis. As a result, nutrients readily available to plants are released, whereas the action of such organic material after its application to the soil is quick $[7,8]$. This explains the positive effect of the action of SMS in this experiment. Gerrits [50] noted that spent mushroom substrate contains, on average, $25-35 \%$ of dry matter, which was confirmed in the present study. A study by Uzun [20] revealed that the N:P:K ratio in spent mushroom compost is 1.9:0.4:2.4 and that it has a strong relationship with SMS storage duration. An Irish study [19] proved that this ratio is 1.2:1.0:1.1. On the other hand, a study conducted in Poland [8], in addition to the present study, demonstrate that the N:P:K ratio in spent mushroom substrate is 1.0:0.4:0.5-0.8. Thus, SMS exhibits a clear phosphorus and potassium deficiency, which justifies supplementary fertilization with these nutrients. Uzun [20] stated that application of SMS in the autumn (similarly as in this study) is the most favorable time, since in this way, one can eliminate the phenomenon of a possible negative impact of initial soil salinity, which sometimes occurs immediately after application of fertilizer in the spring, on young developing plants. Polat et al. [23] are also of the opinion that a drawback of SMS can sometimes be in the form of an excessively high content of soluble salts and their negative effect on plant growth and development, though the above-mentioned risk more applies to greenhouse-grown crops than to field crops.

Wang et al. [51], Bavec et al. [52], Kwiatkowski [25], and Kwiatkowski et al. [3] observed that the yield-increasing effects of different types of fertilization depend, among other 
factors, on the crop plant species, as well as on the type of soil and its initial level of nutrient availability. When we refer this comment to the realities of the experiment in question, we note that under the conditions of medium soil nutrient availability, the most noticeable effect -in the form of increased yield of thyme raw material-was produced by mineral NPK fertilization and SMS fertilization, at a rate of 50\% (but supplemented with $50 \%$ mineral NPK fertilization in the spring). In the opinion of some authors [18,53], SMS fertilization of crop plants is related to weather conditions, notably spent mushroom substrate has a high capacity to retain water in the soil and due to this, a crop culture can better cope with periodic drought conditions. This fact can provide an advantage to SMS over other fertilizers, as regards its effects on crop productivity and yield quality.

\subsection{The Impact of Row Spacing on the Yield and Quality of Thyme Raw Material}

The present study proves that different row spacings in thyme crops (different densities of crop plants in the field) are of smaller and ambiguous importance for the productivity and quality of herbal material compared to the fertilizer and cultivar factors. The wider row spacing $(40 \mathrm{~cm})$ only contributed to obtaining higher thyme yields. The narrower inter-rows $(30 \mathrm{~cm})$ of this herbal plant, in turn, resulted in achieving some more favorable quality parameters (essential oil content, polyphenol content, and ORAC antioxidant activity). Row spacing was not of major significance in the case of characteristics such as the flavonoid content, DPPH radical scavenging activity, and FRAP reducing power. The study on chamomile by Kwiatkowski [25] revealed that a wider row spacing $(45 \mathrm{~cm})$ also promoted higher yields of this herbal plant than a narrower row spacing of $35 \mathrm{~cm}$, but in that study, a row spacing of $25 \mathrm{~cm}$ was studied. The widest row spacing $(45 \mathrm{~cm})$ and also a spacing of $35 \mathrm{~cm}$ showed similar effects on the quality parameters of chamomile (essential oil and flavonoid content)—significantly higher relative to a row spacing of $25 \mathrm{~cm}$. Salomon [54] did not find row spacing to have a significant impact on the quality parameters of chamomile. In turn, a study conducted in a pot marigold plantation shows that extreme values (the lowest one being 30 plants per $1 \mathrm{~m}^{2}$ and the highest one being 90 plants per $1 \mathrm{~m}^{2}$ ) of plant density result in lower yields and quality of pot marigold raw material than a density of 50-70 plants per $1 \mathrm{~m}^{2}$ [27]. Similar observations can also be made based on a study by Shakib et al. [55].

\section{Conclusions}

The common thyme Polish cultivar "Słoneczko" (popular in agricultural practice) showed greater suitability for cultivation than the Romanian cultivar "De Dolj", which is less known in Poland. Cv. "Słoneczko" was characterized by higher total yield of herbal material and generally had a more favorable chemical composition of raw materials than cv. "De Dolj".

Among the fertilizers and their combinations tested in this experiment, mineral NPK fertilization and fertilization with spent mushroom substrate (SMS) at a 50\% rate + mineral NPK fertilization at a 50\% rate had the most beneficial effect on thyme yield. SMS fertilization, on the other hand, had the greatest positive impact on the quality and antioxidant properties of thyme raw material (a higher content of essential oil, polyphenols, and flavonoids, as well as better properties related to free radical scavenging and antioxidant activity), in particular, at a rate of $100 \%$ or at a rate of $70 \%$ SMS $+30 \%$ NPK.

In the cultivation of thyme, a wider row spacing of $40 \mathrm{~cm}$, proved to be more favorable from the point of view of total yield. A narrower row spacing $(30 \mathrm{~cm})$, on the other hand, positively affected most of the chemical composition indicators of the thyme raw material.

Significant interactions between thyme cultivars and methods of fertilization, as well as between fertilization methods and row spacings, have been demonstrated-affecting the quality parameters of the raw material. The following treatment combination produced the most favorable quality parameters: cv. "Słoneczko" grown at a narrower row spacing $(30 \mathrm{~cm})$, with application of $100 \%$ SMS fertilization or $70 \%$ SMS + 30\% NPK fertilization. 
To sum up, the research hypothesis adopted in this study was confirmed. The high suitability of SMS in thyme fertilization was proven from the point of view of the healthpromoting properties of the herbal material, but also due to its positive effect on yield (SMS supplemented with NPK fertilization). Moreover, SMS fertilization proved to be more beneficial than manure fertilization in all aspects. Conventional $100 \%$ mineral NPK fertilization only had a positive effect on thyme yield.

Author Contributions: C.A.K. and E.H. conceptualization; C.A.K. and E.H. formal analysis; C.A.K. and E.H. investigation and methodology; E.H. and C.A.K. resources, C.A.K. and E.H. writing-original draft. All authors have read and agreed to the published version of the manuscript.

Funding: This research was funded by the Ministry of Science and Higher Education of Poland as part of the statutory activities of the Department of Herbology and Plant Cultivation Techniques (RKU/DS/4), University of Life Sciences in Lublin.

Institutional Review Board Statement: Not applicable.

Informed Consent Statement: Not applicable.

Data Availability Statement: Not applicable.

Conflicts of Interest: The authors declare no conflict of interest.

\section{References}

1. Thompson, J.D.; Manicacci, D.; Tarayre, M. Thirty-five years of thyme: A tale of two polymorphisms. BioScience 1998, 48, 805-815. [CrossRef]

2. Borgen, A.; Davanlou, M. Biological control of com-mon bunt (Tilletia tritici) in organic agriculture. J. Crops Prod. 2000, 3, 157-171. [CrossRef]

3. Kwiatkowski, C.A.; Haliniarz, M.; Harasim, E.; Kołodziej, B.; Yakimovich, A. Foliar applied biopreparations as a natural method to increase the productivity of garden thyme (Thymus vulgaris L.) and to improve the quality of herbal raw material. Acta Sci. Pol. Hortorum Cultus 2020, 19, 107-118. [CrossRef]

4. Lau, K.L.; Tsang, Y.Y.; Chiu, S.W. Use of spent mushroom compost to bioremediate PAH-contaminated samples. Chemosphere 2003, 52, 1539-1546. [CrossRef]

5. Singh, A.D.; Vilkineswary, S.; Abdullah, N.; Sekaran, M. Enzymes from spent mushroom substrate of Pleurotus sajor-caju for the decolourisation and detoxification of textile dyes. World J. Microbiol. Biotechnol. 2011, 27, 535-545. [CrossRef]

6. Williams, B.C.; McMullans, S.; McCahey, S. An initial assessment of spent mushroom compost as a potential energy feedstock. Bioresour. Technol. 2001, 79, 227-230. [CrossRef]

7. Jasińska, A. Spent mushroom compost (SMC)—Retrieved added value product closing loop in agricultural production. Acta Agrar. Debr. 2018, 150, 185-202. [CrossRef]

8. Kwiatkowski, C.A.; Harasim, E.; Yakimovich, A.; Kołodziej, B.; Tomczyńska-Mleko, M. Evaluation of spent mushroom substrate, mineral NPK fertilization and manure fertilization on chamomile (Chamomila recutita L. Rausch) yield and raw material quality. Acta Sci. Pol. Hortorum Cultus 2018, 17, 3-16. [CrossRef]

9. Jordan, S.N.; Mullen, G.J.; Murphy, M.C. Composition variability of spent mushroom compost in Ireland. Bioreosur. Technol. 2008, 99, 411-418. [CrossRef]

10. Paredes, C.; Medina, E.; Moral, R.; Perez-Murcia, M.D.; Moreno-Caselles, J.; Bustamante, M.A.; Cecilia, J.A. Characterization of the different organic matter fractions of spent mushroom substrate. Commun. Soil Sci. Plant Anal. 2009, 40, 150-161. [CrossRef]

11. Elsakhawy, T.A.; Abd El-Rahem, W.T. Evaluation of Spent Mushroom Substrate Extract as a Biofertilizer for Growth Improvement of Rice (Oryza sativa L.). Egypt. J. Soil. Sci. 2020, 60, 31-42. [CrossRef]

12. Machado, A.M.B.; Souse Dias Santos, E.E.C.; Freitas, R.T.F. Spent mushroom substrate of Agaricus bluzei in broiler chicks diet. Rev. Bras. Zootec. 2007, 36, 1113-1118. [CrossRef]

13. Azevedo, R.S.; Ávila, C.L.S.; Sousa Dias, E.; Bertechini, A.G.; Schwan, R.F. Utilization on the spent substrate of Pleurotas sajor caju mushroom in broiler chicks ration and the effect on broiler chicken performance. Acta Sci. Anim. Sci. 2009, 31, 139-144. [CrossRef]

14. Curtis, J.; Suess, A. Report: Value-Added Strategies for Spent Mushroom Substrate in BC; British Columbia Ministry of Agricultural and Lands: Victoria, BC, Canada, 2006.

15. Guo, M.X.; Chorover, J. Leachate mitigation from spent mushroom substrate through intact and repacked subsurface soil columns. Waste Manag. 2006, 26, 133-140. [CrossRef] [PubMed]

16. Medina, E.; Paredes, C.; Bastamante, M.A.; Moral, R.; Moreno-Caselles, J. Relationships between soil physico-chemical, chemical and biological properties in a soil amended with spent mushroom substrate. Geoderma 2012, 173, 152-161. [CrossRef]

17. Maher, M.J.; Smyth, S.; Dodd, V.A.; McCabe, T.; Magette, W.L.; Duggan, J.; Hennerty, M.J. Managing Spent Mushroom Compost; Teagasc: Dublin, Ireland, 2000; pp. 111-121. 
18. Song, L.; Siu-Wai, C. Dual roles of spent mushroom substrate on soil improvement and enhanced drought tolerance of wheat Triticum aestivum. In Proceedings of the International Conferences, 3rd QLIF Congress, Crop Production, Soil Management, Stuttgart, Germany, 20-23 March 2007.

19. Jordan, S.N.; Mullen, G.J. Spend mushroom legislation in Ireland. Proc. ESAI Environ. 2007, 37-41.

20. Uzun, I. Use of spent mushroom compost in sustainable fruit production. J. Fruit Ornam. Plant Res. 2004, 12, 157-165.

21. Roy, S.; Barman, S.; Chakraborty, U.; Chakraborty, B. Evaluation of spent mushroom substrate as biofertilizer for growth improvement of Capsicum annuum L. J. Appl. Biol. Biotechnol. 2015, 3, 22-27. [CrossRef]

22. Rao, J.R.; Watabe, M.; Stewart, T.A.; Millar, B.C.; Moore, J.E. Pelleted organo-mineral fertilizers from composted pig slurry solids, animal wastes and spent mushroom compost for amenity grasslands. Waste Manag. 2007, 27, 1117-1128. [CrossRef]

23. Polat, E.; Uzun, I.H.; Topcuoglu, B.; Önal, K.; Onus, A.N.; Karaca, M. Effects of spent mushroom compost on quality and productivity of cucumber (Cucumis dativus L.) grown in green-houses. Afr. J. Biotechnol. 2009, 8, 176-180.

24. Salomez, J.; De Bolle, S.; Sleutel, S.; De Neve, S.; Hofman, G. Nutrient Legislation in Flanders (Belgium). In Proceedings, More Sustainability in Agriculture: New Fertilizers and Fertilization Management; CRA, Agricultural Research Council: Rome, Italy, 2009; pp. 546-551.

25. Kwiatkowski, C.A. Yield and quality of chamomile (Chamomilla recutita (L.) Rausch.) raw material depending on selected foliar sprays and plant spacing. Acta Sci. Pol. Hortorum Cultus 2015, 14, 143-156.

26. Kwiatkowski, C.A.; Haliniarz, M.; Harasim, E. Weed infestation and health of organically grown Chamomile (Chamomilla recutita (L.) Rausch) depending on selected foliar sprays and row spacing. Agriculture 2020, 10, 168. [CrossRef]

27. Kwiatkowski, C.A.; Harasim, E.; Yakimovich, A. Effect of nitrogen fertilization and plant density on seed yield and fat content and quality of pot marigold (Calendula officinalis L.) under climatic conditions of Belarus. Acta Sci. Pol. Hortorum Cultus 2020, 19, 3-12. [CrossRef]

28. Panaitescu, L.; Niță, S.; Lungu, M.L.; Niță, L.D.; Shenk, I. Contributions to the implementation of sustainable technologies for the cultivation of thyme (Thymus vulgaris L.) in the dobrodgea plateau. Res. J. Agric. Biol. Sci. 2019, 51, $172-177$.

29. IUSS Working Group WRB. World Reference Base for Soil Resources 2014, Update 2015. In International Soil Classification System for Naming Soils and Creating Legends for Soil Maps; World Soil Resources Reports No. 106; FAO: Rome, Italy, 2015.

30. Polish Pharmacopoeia IX; PTFarm: Warszawa, Poland, 2011.

31. Singleton, V.L.; Rossi, J.A. Colorimetry of total phenolics with phosphomolybdic phosphotungstic acid reagents. Am. J. Enol. Viticult. 1965, 16, 144-158.

32. Slinkard, K.; Singleton, V.L. Total phenol analyses: Automation and comparison with manual methods. Am. J. Enol. Viticult 1977, $28,49-55$.

33. Chen, J.H.; Ho, C.T. Antioxidant activities of caffeic acid and its related hydroxycinnamic acid compounds. J. Agric. Food Chem. 1997, 45, 2374-2378. [CrossRef]

34. Re, R.; Pellegrini, N.; Proteggente, A.; Pannala, A.; Yang, M.; Rice-Evans, C. Antioxidant activity applying an improved ABTS radical cation decolorization assay. Free Radic. Biol. Med. 1999, 26, 1231-1237. [CrossRef]

35. Benzie, I.F.F.; Strain, J.J. The ferric reducing ability of plasma (FRAP) as a measure of "antioxidant power": The FRAP assay. Anal. Biochem. 1996, 239, 70-76. [CrossRef] [PubMed]

36. Eudoxie, G.; Alexander, I.A. Spent Mushroom Substrate as a Transplant Media Replacement for Commercial Peat in Tomato Seedling Production. J. Agric. Sci. 2011, 3, 41-49. [CrossRef]

37. Zhang, R.H.; Duan, Z.Q.; Li, Z.G. Use of spent mushroom substrate as growing media for tomato and cucumber seedlings. Pedosphere 2012, 22, 333-342. [CrossRef]

38. Ashrafi, R.; Rajib, R.R.; Sultana, R.; Rahman, M.; Mian, M.H.; Shanta, F.H. Effect of spent mushroom compost on yield and fruit quality of tomato. Asian J. Med. Biol. Res. 2015, 1, 471-477. [CrossRef]

39. Ishihara, A.; Ando, K.; Yoshioka, A.; Murata, K.; Kokubo, Y.; Morimoto, N.; Ube, N.; Yabuta, Y.; Ueno, M.; Tebayashi, S.; et al. Induction of defense responses by extracts of spent mushroom substrates in rice. J. Pestic. Sci. 2019, 44, 89-96. [CrossRef] [PubMed]

40. Medina, E.; Paredes, C.; Pérez-Murcia, M.D.; Bustamante, M.A.; Moral, R. Spent mushroom substrates as component of growing media for germination and growth of horticultural plants. Bioresour. Technol. 2009, 100, 4227-4232. [CrossRef]

41. Sendi, H.; Mohamed, M.T.M.; Anwar, M.P.; Saud, H.M. Spent mushroom waste as a media replacement for peat moss in kai-lan (Brassica oleracea var. Alboglabra) production. Sci. World J. 2013, 8. [CrossRef]

42. Prabu, M.; Jeyanthi, C.; Kumuthakalavalli, R. Spent mushroom substrate: An enriched organic manure for improving the yield of Vigna unguiculata (L.) Walp (Cowpea) leguminous crop. SIRJ-APBBP 2014, 1, 7-14.

43. Afagh, H.V.; Saadatmand, S.; Riahi, H.; Khavari-Nejad, R.A. Influence of Spent Mushroom Compost (SMC) as an Organic Fertilizer on Nutrient, Growth, Yield, and Essential Oil Composition of German Chamomile (Matricaria recutita L.). Commun. Soil Sci. Plant Anal. 2019, 50, 1-11. [CrossRef]

44. Cao, G.; Prior, R.L. The measurement of oxygen radical absorbance capacity in biological samples. Meth. Enzymol. 1999, $229,50-62$. [CrossRef]

45. Zu, Y.; Yu, H.; Liang, L.; Fu, Y.; Efferth, T.; Liu, X.; Wu, N. Activities of ten essential oils towards Propionibacterium acnes and PC-3, A-549 and MCF-7 cancer cells. Molecules 2010, 15, 3200-3210. [CrossRef]

46. Amorati, R.; Foti, M.C.; Valgimigli, L. Antioxidant activity of essential oils. J. Agric. Food Chem. 2013, 61, 10835-10847. [CrossRef] 
47. Rouseff, R.L.; Nagy, S. Health and nutritional benefits of citrus fruit components. Food Technol. 1994, 11, 125-132.

48. Katsube, N.; Iwashita, K.; Tsushida, T.; Yamaki, K.; Kobori, M. Induction of apoptosis in cancer cells by bilberry (Vaccinium myrtillus) and the anthocyanins. J. Agric. Food Chem. 2003, 51, 68-75. [CrossRef] [PubMed]

49. Dunbar, J.; Wong, D.C.L.; Yarus, M.J.; Forney, L.J. Autoradiographic method for isolation of diverse microbial species with unique catabolic traits. Appl. Environ. Microbiol. 1996, 62, 4180-4185. [CrossRef] [PubMed]

50. Gerrits, J.P.G. Composition, use and legislation of spent mushroom substrate in Netherlands. Compost Sci. Util. 1994, 2, 24-30. [CrossRef]

51. Wang, Z.H.; Li, S.X.; Malhi, S. Effect of fertilization and other agronomic measures on nutritional quality of crops. J. Sci. Food Agric. 2008, 88, 7-23. [CrossRef]

52. Bavec, M.; Narodoslawsky, M.; Bavec, F.; Turinek, M. Ecological impact of wheat and spelt production under industrial and alternative farming systems. Renew. Agric. Food. Syst. 2012, 27, 242-250. [CrossRef]

53. Guo, M.; Chorover, J. Solute release from weathering of spent mushroom substrate under controlled conditions. Compost. Sci. Util. 2004, 12, 225-234. [CrossRef]

54. Salomon, I. Growing conditions and the essential oil of chamomile (Chamomilla recutita (L.) Raushert). J. Herbs Spice Med. Plants 1994, 2, 31-37. [CrossRef]

55. Shakib, A.; Nejad, A.R.; Khalighi, A.H.M. Changes in seed and oil yield of Calendula officinalis L. as affected by different levels of nitrogen and plants density. Res. Crops 2010, 11, 728-732. 